\title{
The impact of artificial mycorrhizal inoculation on the growth of common oak seedlings and development of mycorrhiza: Inoculation may not positively affect growth of seedlings
}

\author{
JAROSLAV HOLUŠA ${ }^{1}$ \\ VÍTĚZSLAVA PEŠKOVÁ*1 \\ FRANTIŠEK LORENC ${ }^{1}$ \\ ${ }^{1}$ Faculty of Forestry and Wood Sciences \\ Czech University of Life Sciences Prague \\ Kamýcká 129, Prague 6, 165 21, Czech Republic \\ Correspondence: \\ Vítězslava Pešková \\ E-mail: peskovav@fld.czu.cz
}

Key words: ectomycorrhiza, inoculation, mycorrhizal symbiosis, roots, Quercus robur
Received December 18, 2015.

Revised January 24, 2016.

Accepted January 25, 2016

\section{Abstract}

Background and Purpose: This study evaluated the effect of the $V A M B A C^{\odot}$ mycorrhizal inoculum on the growth and mycorrhizal characteristics of $\mathrm{Quercus}$ robur seedlings.

Materials and Methods: The oak seedlings soaked in an inoculum containing mycorrhizal fungi were planted on six study plots. The non-inoculated seedlings were planted on control plots. Two-year-old plants were evaluated at three of the plots, while 9-to-10-year-old plants were assessment at the remaining three plots. Seedlings' above-ground height, main root length, root dry mass, above-ground dry mass and stem diameter were evaluated. For five plants, mycorrhizal characteristics (the density of active and inactive mycorrhizae and the proportion of active mycorrhizae) were also studied in the laboratory.

Results and Conclusions: Inoculated seedlings demonstrated signifcantly higher proportion of active mycorrhizae in all plots as well as a higher density of active mycorrhizae only on some studied plots when compared to control. Among growth characteristics, inoculated seedlings demonstrated higher values for all evaluated variables. The most striking differences were observed in stem diameter, which was significantly different for all young stands and for one plantation. For the remaining growth characteristics, inoculated and control seedlings displayed significant differences only on some plots. These results showed that artificial mycorrhizal inoculation can be used in forestry practice, but its effects may not always be necessarily positive.

\section{INTRODUCTION}

Tn consequence of global climate change, forests in Europe will face not only changes in average values for climatic factors, but also higher variations associated with more extreme weather fluctuations, e.g. longer drought periods, storms and floods (1). Oak forests have been damaged by drought in large areas in Europe. Such conditions activate a number of pathogenic fungi (2). A significant treat is Phytophthora cinnamomi Rands 1922, an oomycete attacking oak roots in forests, which increases in severity particularly during long periods of drought, higher summer temperatures and long periods of high temperatures combined with short and intense precipitation (3). In Central and Eastern Europe, however, this oomycete will likely not spread significantly 
due to cold winters (4). There is also a threat for the introduction of the allochtonous fungal species, especially Ceratocystis fagacearum (Bretz) J. Hunt, imperfect stage Chalara quercina Henry, which causes so-called oak wilt in North America and is carried by insect vectors.

The central Morava River alluvial plain (in the eastern Czech Republic) is an area of oak dieback. Permanent decrease in the level of ground water, an initial factor in oak wasting, has probably been accompanied infection honey fungus Armillaria mellea (Vahl.) P. Kumm., ultimately leading to oak mortality (own observation). The ash is the second economically crucial tree in the region, which is currently infected by the fungus Hymenoscyphus fraxineus, both in the wild and on plantations (5). This has led foresters to abandon the renewal of this tree (own observation). Successful renewal of oak stands is therefore important in future.

Foresters began semi-operational testing of the possibility of supporting seedling vitality by artificially inoculating bare-root seedlings with mycorrhizal fungi before planting (Holuša observ.). Artificial inoculation's main objectives include the improving of seedlings' successful survival, after transplantation and the stimulation of their further efficient growth under stress conditions. Improvement of health also leads to increased resistance against various abiotic influences and harmful biotic agents (6).

GRYNDLER et al. (7) draw attention to the fact that research results exhibiting unsuccessful inoculation (i.e. which did not show a beneficial effect from mycorrhizal symbiosis on plant growth and health) are rarely published (e.g. 8). A simple comparison of the number of successful and unsuccessful inoculations in published studies would therefore be considerably confusing for evaluating mycorrhizal inoculation use in practice. In addition, most studies examining the effect of artificial inoculation on tree growth are short-term and frequently involve seedlings grown under artificial conditions. Long-term research including young trees and research on seedlings growing under natural conditions are quite rare (7).

LAZEREVIĆ et al. (9) emphasized the need for longterm field observations to compare the effects of various treatments as well as treatments with various ectomycorrhizal fungi on the survival and growth of outplanted seedlings (9). For example, experiments on oaks in containers have been published by MITCHELL et al. (1984), LUNT et HEDGER (2003), NÚNEEZ et al. (2006), and HERMANN et al. (2004), while data from greenhouses have been published by PRUETT et al. (2008) and data from the field by GARBAYE et CHULIN (1997) (10-15).

The objective of our study was to compare the effect of artificial inoculation of Quercus robur L. plants on their growth after 2 and 9-10 years of being planted in nature.

\section{MATERIAL AND METHODS}

The effect of the VAMBAC ${ }^{\bullet}$ mycorrhizal preparation from Biotechnology, a. s. (Czech Republic) on Quercus robur seedlings' growth and development was evaluated at six study plots. All plots were situated in one locality in the Upper Moravian Vale near the municipality of Střen

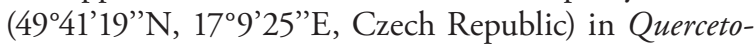
Fagetum forest zone with mesotrophic Cambisols on plain terrain. The plots were $0.7-1$ ha, elongated and with north-south orientation. The distance between plots was $<1 \mathrm{~km}$. The plots were surrounded by mixed forest stands of various ages.

Each plot was divided lengthwise in the north-south direction into two sections. In 0.3 ha of the first of the two sections the seedlings were treated with the VAMBAC ${ }^{\odot}$ mycorrhizal preparation after planting (Table 1). The preparation was a mixture of powdery and liquid components, according to production containing isolates of mycorrhizal fungi with fixation powder. The preparation contained 6 genera of ectomycorrhizal fungi (the genera Cenococcum, Hebeloma, Laccaria, Paxillus, Rhizopogon, and Scleroderma) (16). More information about $\mathrm{VAMBAC}^{\odot}$ has not been found out. Since planting was done in forests, the soil was not mechanically agitated. Cambisols were loamy, more than $1 \mathrm{~m}$ deep and without stones larger than $1 \mathrm{~cm}$.

Seedling roots were thoroughly soaked in the mixture in bundles of 10, and the seedlings were then immediately planted in April. Un-inoculated seedlings were planted in the other 0.3 ha section of the plot as controls. At total, 5,000 seedlings (stem diameter $5 \mathrm{~mm}$, height $18-22 \mathrm{~cm}, 4$ years old) per hectare were planted on the plots. To test the long-term effects of mycorrhizal inoculation, seedling characteristics were determined in twoyear-old plantation and in 9-to-10-year-old young stands (Table 1).

During 9-10 October 2009, the oak seedlings' growth characteristics were evaluated in all plots. For plantations, this included measuring stem diameter of control and inoculated seedlings at ground level. For young stands,

Table 1. Altitudes and the year of inoculation of oak seedlings in study plots

\begin{tabular}{|lcc|}
\hline Plot & Altitude $(\mathrm{m})$ & $\begin{array}{c}\text { Year preparation } \\
\text { applied }\end{array}$ \\
\hline Plantation A & 280 & 2008 \\
Plantation B & 250 & 2008 \\
Plantation C & 249 & 2008 \\
Young stand A & 260 & 2000 \\
Young stand B & 250 & 1999 \\
Young stand C & 250 & 2000 \\
\hline
\end{tabular}




\section{Evaluation parameters:}

1. Density of active mycorrhizae - calculated as average value of determined number of active mycorrhizal tips associated with $1 \mathrm{~cm}$ of root length $(\mathrm{cm}-1)$

2. Density of inactive mycorrhizae - calculated as average value of determined number of inactive mycorrhizal tips associated with $1 \mathrm{~cm}$ of root length $(\mathrm{cm}-1)$

3. Proportion of active mycorrhizae - ratio of active to total mycorrhizal tips (\%)

4. Above-ground height - measured from ground to top of the terminal bud $(\mathrm{cm})$

5. Maximum root length - measured from stem to tip or end of the intentionally modified root section $(\mathrm{cm})$

6. Root dry mass - average root dry mass (g)

7. Above-ground dry mass - average above-ground part dry mass (g)

8. $\quad$ stem diameter $(\mathrm{cm})$

only stem diameter was measured. At each plot 50 oak seedlings were evaluated. They were placed in one line in the central part of treated as well as control plot. Weed infestation was strong in all plots, and coverage by grass and other plants was $>90 \%$.

Five treated and five control seedlings from each plantation (30 seedlings in total) were dug out of the ground and then measured for above-ground height $(\mathrm{cm})$, maximum root length $(\mathrm{cm})$ with a folding meter, stem diameter $(\mathrm{mm})$ with a sliding ruler, above-ground dry mass, and root dry mass with a scale measuring grams (g). Seedlings of average height were chosen in the central line of seedling growing $10 \mathrm{~m}$ from the edge of plot. Each tenth seedling was studied. From 9-to-10-year-old stands, five soil probes from treated sections and five soil probes from control sections ( 30 probes in total) were collected using a root drill with internal diameter of $6 \mathrm{~cm}$ and depth of $15 \mathrm{~cm}$, equipped with a sawing blade for cutting roots. Probe contents were separated in the laboratory and individual root segments were classified into three size categories according to root diameter (root segments with diameters $<1 \mathrm{~mm}, 1-2 \mathrm{~mm}$, and $>2 \mathrm{~mm}$ ).

Mycorrhizal characteristics were evaluated using the method of identifying all active and inactive mycorrhizal tips (17). The main unit for determining the number of mycorrhizae was a root segment of $5 \mathrm{~cm}$ in length and less than $1 \mathrm{~mm}$ in diameter. Twenty root segments from each sample were evaluated under stereomicroscope at $40 \times$ magnification. Tips with developed hyphal mantle, without root hairs, smooth on the surface and light in colour were classified as "active mycorrhizae". Tips lacking hyphal mantle and wrinkled surfaces were classified as "inactive mycorrhizae" (18-19). The degree of mycorrhizal colonization was evaluated using two parameters: mycorrhizal tip density and proportion. The density of active and inactive mycorrhizae was calculated as the number of active (inactive) mycorrhizal tips associated with $1 \mathrm{~cm}$ of root length. The proportion of active mycorrhizae was calculated as the number of active mycorrhizal tips to all (both active and inactive) mycorrhizal tips (20).
The evaluated parameters of inoculated and control oak seedlings were compared statistically using Statistica 12 software (StatSoft, Inc., Tulsa, OK, USA, 2013). The comparison was done separately for each location, as individual plots differed in seedling age and stand conditions (see Table 1). The data were tested for normality using the Shapiro-Wilk test. Since the evaluated parameters were not normally distributed, the non-parametric Mann-Whitney test was used for their comparison. Dry mass of above-ground plant and the root sections collected on 2-year-old plantation plots was not statistically processed as a result of the weighing procedure whereby all inoculated and control seedling sections for each plot were dried and weighed together and a sufficient quantity of tested samples was therefore not obtained.

The collected seedlings' root systems (from the whole probe) and above-ground sections were subsequently used to determine dry mass. The samples were dried in a dryer at $105^{\circ} \mathrm{C}$ and then weighed on electronic scale (with accuracy $0.01 \mathrm{~g}$ ).

\section{RESULTS}

Root dry mass was significantly greater for inoculated seedlings only in 9-to-10year-old stand B for mass of roots less than $1 \mathrm{~mm}$ in diameter (Table 2). In all other cases, no significant differences between inoculated and control seedlings were found for dry mass of total roots or roots with diameter $<1 \mathrm{~mm}, 1-2 \mathrm{~mm}$, or $>2 \mathrm{~mm}$ (Table 3).

The proportion of active mycorrhizae was significantly greater for inoculated seedlings on all plots (Tables 2, 3). The density of active mycorrhizae was significantly greater for inoculated seedlings in all plantations. In 9-10-year-old stands, the density of active mycorrhizae for inoculated seedlings was significantly greater only in young stand A (Table 3). The density of inactive mycorrhizae was significantly greater for control seedlings in plantation B and young stand C, while on the remaining 
Table 2. Values of mycorrhizal characteristics and root dry mass of oak plants (mean \pm SE) in study plots (plantation...2-year-old trees; young stands... 9-to-10-year-old young trees)

\begin{tabular}{|c|c|c|c|c|c|c|}
\hline \multirow[t]{2}{*}{ Plots } & A & A & B & B & $\mathrm{C}$ & $\mathrm{C}$ \\
\hline & inoculated & control & inoculated & control & inoculated & control \\
\hline \multicolumn{7}{|c|}{ Plantation } \\
\hline Density of active mycorrhizae $\left(\mathrm{cm}^{-1}\right)$ & $2.0 \pm 0.2$ & $0.9 \pm 0.3$ & $2.3 \pm 0.2$ & $1.3 \pm 0.1$ & $2.2 \pm 0.2$ & $1.1 \pm 0.1$ \\
\hline Density of inactive mycorrhizae $\left(\mathrm{cm}^{-1}\right)$ & $1.3 \pm 0.1$ & $1.9 \pm 0.2$ & $1.4 \pm 0.2$ & $2.3 \pm 0.2$ & $1.6 \pm 0.2$ & $1.8 \pm 0.1$ \\
\hline Total density of mycorrhizae $\left(\mathrm{cm}^{-1}\right)$ & $3.3 \pm 0.3$ & $2.8 \pm 0.5$ & $3.7 \pm 0.3$ & $3.6 \pm 0.3$ & $3.8 \pm 0.4$ & $2.8 \pm 0.2$ \\
\hline Proportion of active mycorrhizae (\%) & $61.3 \pm 2.0$ & $31.4 \pm 3.7$ & $61.1 \pm 3.0$ & $35.1 \pm 2.7$ & $57.3 \pm 1.0$ & $36.3 \pm 2.6$ \\
\hline \multicolumn{7}{|c|}{ Young stands } \\
\hline Density of active mycorrhizae $\left(\mathrm{cm}^{-1}\right)$ & $1.8 \pm 0.1$ & $1.2 \pm 0.0$ & $1.6 \pm 0.4$ & $1.3 \pm 0.2$ & $1.5 \pm 0.1$ & $1.2 \pm 0.2$ \\
\hline Density of inactive mycorrhizae $\left(\mathrm{cm}^{-1}\right)$ & $1.4 \pm 0.1$ & $1.5 \pm 0.1$ & $1.1 \pm 0.2$ & $1.7 \pm 0.2$ & $0.9 \pm 0.1$ & $1.7 \pm 0.0$ \\
\hline Total density of mycorrhizae $\left(\mathrm{cm}^{-1}\right)$ & $3.2 \pm 0.2$ & $2.7 \pm 0.1$ & $2.7 \pm 0.6$ & $3.0 \pm 0.5$ & $2.4 \pm 0.2$ & $2.9 \pm 0.2$ \\
\hline Proportion of active mycorrhizae (\%) & $56.7 \pm 2.0$ & $44.3 \pm 1.3$ & 57. \pm 2.85 & $43.23 \pm 1.87$ & $63.07 \pm 1.08$ & $39.76 \pm 2.82$ \\
\hline Root dry mass < $1 \mathrm{~mm} \mathrm{(g)}$ & $0.10 \pm 0.01$ & $0.12 \pm 0.02$ & $0.27 \pm 0.02$ & $0.17 \pm 0.02$ & $0.10 \pm 0.02$ & $0.15 \pm 0.02$ \\
\hline Root dry mass $1-2 \mathrm{~mm}(\mathrm{~g})$ & $0.44 \pm 0.06$ & $0.28 \pm 0.08$ & $0.24 \pm 0.04$ & $0.38 \pm 0.10$ & $0.18 \pm 0.03$ & $0.09 \pm 0.02$ \\
\hline Root dry mass $>2 \mathrm{~mm}(\mathrm{~g})$ & $0.49 \pm 0.36$ & $0.12 \pm 0.05$ & $0.54 \pm 0.23$ & $0.75 \pm 0.39$ & $0.31 \pm 0.13$ & $0.06 \pm 0.03$ \\
\hline Total root dry mass $(\mathrm{g})$ & $1.03 \pm 0.34$ & $0.52 \pm 0.10$ & $1.05 \pm 0.23$ & $1.31 \pm 0.48$ & $0.59 \pm 0.14$ & $0.31 \pm 0.05$ \\
\hline
\end{tabular}

Table 3. The results of the Mann-Whitney U-test for studied variables (plantation...2-year-old trees; young stands... 9-to-10-year-old young trees; *..p ${ }^{*} 0.05 ;{ }^{* *} \ldots p<0.01$; *** .. $p<0.001$ ).

\begin{tabular}{|c|c|c|c|c|c|c|}
\hline Variable & Plantation & Plantation & Plantation & Young stand & Young stand & Young stand \\
\hline Plot & A & B & $\mathrm{C}$ & A & B & $\mathrm{C}$ \\
\hline Above-ground height & 889.5 n.s. & 948.5 n.s. & $788^{* *}$ & - & - & - \\
\hline Stem diameter & 814.5 n.s. & 913 n.s. & $547^{* * *}$ & $701^{* *}$ & $679.5^{* *}$ & $469^{* * *}$ \\
\hline Maximum root length & 10 n.s. & 9.5 n.s. & $1^{*}$ & - & - & - \\
\hline Root dry mass $<1 \mathrm{~mm}$ & - & - & - & 11.5 n.s. & $1.5^{*}$ & 4.5 n.s. \\
\hline Root dry mass $1-2 \mathrm{~mm}$ & - & - & - & 6 n.s. & 7 n.s. & 4.5 n.s. \\
\hline Root dry mass $>2 \mathrm{~mm}$ & - & - & - & 10.5 n.s. & 12 n.s. & 3.5 n.s. \\
\hline Total root dry mass & & & & 6 n.s. & 12 n.s. & 5.5 n.s. \\
\hline Proportion of active mycorrhizae & $0^{*}$ & $0^{*}$ & $0^{*}$ & $0^{*}$ & $0^{*}$ & $0^{*}$ \\
\hline Density of active mycorrhizae & $2^{*}$ & $1^{*}$ & $1^{*}$ & $0^{*}$ & 9 n.s. & 6 n.s. \\
\hline Density of inactive mycorrhizae & 3 n.s. & $1^{*}$ & 8 n.s. & 8 n.s. & 4 n.s. & $0^{*}$ \\
\hline Total density of mycorrhizae & 6 n.s. & 12 n.s. & 4 n.s. & 3 n.s. & 10 n.s. & 3 n.s. \\
\hline
\end{tabular}

plots these differences were not statistically significant (Tables 2, 3).

Above-ground height and stem diameter were significantly higher at inoculated seedlings compared with the control in plantation $\mathrm{C}$, while in plantation $\mathrm{A}$ and $\mathrm{B}$ these characteristics were not significantly different. In all 9-to10 -year-old stands, stem diameters were greater for inoculated seedlings (Figure 1, Table 3).

\section{DIsCussION}

Not much data exists on use of VAMBAC ${ }^{\circ}$, and it is difficult to compare those that do exist. VON BENNEWITZ and HLUSEK (2006) tested the effect of VAMBAC $^{\circ}$ and Amalgerol inoculation preparations on two-year-old apple (Malus sp.) trees in plastic containers in sandy clay soil under the climatic conditions of South Moravia. Even though one of the preparations had an 

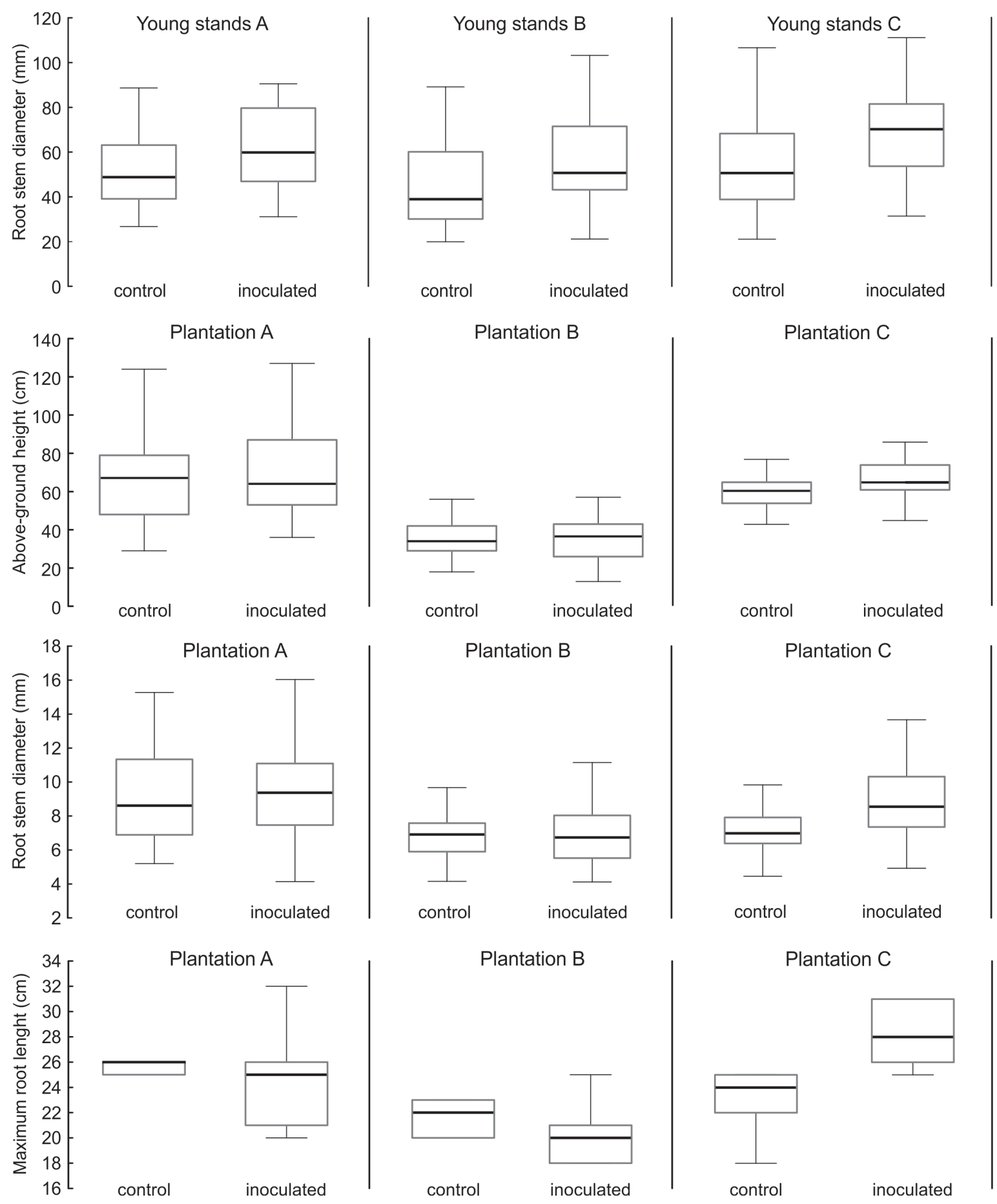

Figure 1. Height, stem diameter and root length of inoculated and control oaks in study plots (plantation...2-year-old trees; young stands... 9-to-10-year-old young trees; line - median, box plot-25\% and 75\% quantiles, whiskers - non-outlier range)

identical name the one in our study, it contained Glomus and Gigaspora arbuscular fungi as well as the rhizospheric bacteria Agrobacterium radiobacter (Beijerinck and van Delden) Conn (21). A VAMBAC ${ }^{\circ}$ preparation with identical composition, the same as in the our study, was tested by TUČEKOVÁ et al. (16) on Norway spruce seedlings in west-northern Slovakia following a large-scale collapse of spruce pure stands in areas of high infection rate of the genera Armillaria and Heterobasidion. These fungi had infected newly planted seedlings. Compared to control plants, treated plants had more developed root systems, particularly in fine roots, as well as higher foliage percent- 
age and longer needles. However, the inoculum had little effect on the growth of above-ground parts. The authors (16) also separately tested the effects of the VAMBAC preparation and the six individual ectomycorrhizal fungi that $\mathrm{VAMBAC}^{\circ}$ contains on spruces in artificial conditions. In such conditions, the best growth characteristics were recorded in seedlings inoculated with the Rhizopogon fungus, followed by seedlings inoculated with the Cenococcum fungus (16). It is apparent that the VAMBAC preparation may not have a positive effect.

Even when using the same preparation (Ectovit) on the same tree species (Picea abies (L.) Karst.) in a single area, different results may be obtained. On stands strongly infected by honey fungus (Armillaria sp.), Ectovittreated spruces compared to untreated trees have significantly greater height, above-ground height, stem diameter, maximum root length, proportion of active mycorrhizae, and rooting rate (22). In another part of the affected area, seedlings' growth characteristics were overall slightly more positive for control seedlings (6). REPÁČ et al. (26), meanwhile, did not record any significant effects from inoculation using the Ectovit inoculation preparation on the growth characteristics of either bare-root or containerized seedlings of $P$. abies, Pinus sylvestris L., Larix decidua Mill., Fagus sylvatica L. and Acer pseudoplatanus L. (23).

We consider the tree species to be undoubtedly an important factor influencing the result of artificial inoculation. The root colonization by a mycorrhizal fungus showed statistically significant differences among individual oak species (Quercus robur, Q. velutina Lam., $Q$. $a l b a \mathrm{~L}$.) as well as among species of ectomycorrhizal fungi (Pisolithus tinctorius $=$ P. arrhizus (Scop.) Rauschert, Suillus granulatus (L.) Roussel, S. luteus (L.) Roussel, Thelephora terrestris Ehrh., Cenococcum geophilum Fr.) in a study in containers (10). In addition, a generally positive inoculation effect on seedling growth has been found on Quercus ilex L. and Q. faginea Lam. in containers (12) and on Q. rubur L. in Petri dishes (13). Similarly, the number of ectomycorrhizal morphotypes in Q. rubra stands was recorded to be increasing with stand age (24).

It is difficult to select a suitable ectomycorrhizal fungus of artificial inoculation for tree species. The ectomycorrhizal fungus should be capable of easily and quickly creating the host plant ectomycorrhizae which are the most effective for the host. In addition, the ectomycorrhizal fungus needs to be well-adjusted to stand conditions in order to grow well in the soil and withstand stress. From a number of laboratory and field studies, it is apparent that there is no universal symbiont for tree species (25).

Inoculated oaks' growth characteristics compared with those of non-inoculated trees depend also on substrate $(10,12)$, which is also known in spruce (26) and pine (27). Specifically, interactions between fungus and substrate can be significant (26) and this may explain the differing results at individual locations in the present study.
Because there are only very few results from field experiments, and particularly from studies covering a long period of time, climate conditions have not been described in detail. It is apparent, however, that some studies' ambiguous results may have been caused by a variability in mycorrhizal fungi presence under natural conditions depending on soil and climatic conditions (6). Water has a crucial effect on the growth of ectomycorrhizal fungi's mycelia. Sufficient water is necessary for the growth of mycelia and sporocarps. It is known that drought crucially limits the creation of sporocarp (fructification) (7). On the other hand, inoculation can improve seedlings' water uptake during summer drought periods (12).

In nature, artificially inoculated seedlings are also subject to external competition $(7,28)$, which probably conceals artificial inoculation's effect on tree growth and mycorrhizal characteristics. Seedlings grown in large nurseries are subject to transplantation stress after being planted in nature. Seedlings which have formed ectomycorrhizae, however, adjust to new stands better and more quickly than non-mycorrhizal seedlings, and their short ectomycorrhizal roots can immediately supply the plant with sufficient nutrients for such period of increased requirements (25). From overall statistical evaluation of a number of studies, it appears that applying an ectomycorrhizal inoculation rarely leads to inhibition of plant growth. Demonstrable stimulation of plant growth occurred in approximately only half of studies (28). The current study support conclusion, that although artificial inoculation may improve survival rate and growth, the results may not always be positive. In the case of using $\mathrm{VAMBAC}^{\circ}$, the ambiguous results may be affected by the fact that, in contrast to artificial substrates, soils on the forested plots contain autochthonous ectomycorrhizal fungi and a wide range of microorganisms able to form symbiotic relationships which can create assumptions that are not investigated. They affect seedling growth, and potentially obscure differences between inoculated and control variants (7). Regarding his experiments with artificial pine inoculation, REPÁC (26) states that pine seedlings are to a significant degree colonized by original, naturally occurring symbiotic fungi (29). Spontaneous mycorrhiza origin thus occurs also in non-inoculated controls, which recorded a higher average values in some experiments (20).

The experimental evaluation yielded ambiguous results. Possible reasons for the results' ambiguity include (i) inoculum quality, (ii) variability in the natural microorganisms present (primary natural mycorrhization) depending on soil conditions, (iii) the effect of unrepeatable climatic conditions, and (iv) potential microclimatic differences during the test period. On the basis of experimental data evaluation, the method of artificially inoculating seedlings cannot be totally excluded from forestry practice as it apparently leads to higher representation of active mycorrhizae, but forest managers could also consider the costs of such measures. 
Acknowledgments: This work was supported by the $\mathrm{Na}$ tional Agency for Agricultural Research of the Ministry of Agriculture of the Czech Republic (NAZV) under Grant QJ1220317 and by Internal Grant Agency of Faculty of Forestry and Wood Sciences, Czech University of Life Sciences in Prague - the project GA FLD A05/15.

\section{REFERENCES}

1. LINDNER M, MAROSCHEK M, NETHRERER S, KREMER A, BARBATI A, GARCIA-GONZALO J, SEIDL R, DELZON S, CORONA P, KOLSTRÖM M, LEXER M J, MARCHETTI M 2010 Climate change impacts, adaptive capacity and vulnerability of European forest ecosystems. Forest Ecol Manag 259: 698-709 http://dx.doi.org/10.1016/j.foreco.2009.09.023

2. KAPITOLA P, KROUTIL P.2011 Karanténní škodlivé organismy na lesních dřevinách. Státní rostlinolékařská správa, Praha, p 63

3. LINDNER M, GARCIA-GONZALO J, KOLSTRÖM M, GREEN T, REGUERA R, MAROSCHEKM, SEIDL R, LEXER M J, NETHERER S, SCHOPF A, KREMER A, DELZON S, BARBATI A, MARCHETTI M, CORONA P 2008 Impact of Climate Change of European Forests and Options for Adaptation. Report to the European Commision Directorate-General for Agriculture and Rural Development, p 173 http://ec.europa.eu/agriculture/analysis/external/euro_forests/full_report_en.pdf

4. BRASIER C M 1996 Phytophthora cinnamomi and oak decline in southern Europe. Environmental constraints including climate change. Ann Sci Forest 53: 347-358 http://dx.doi.org/10.1051/forest:19960217

5. HAVRDOVÁ L, ČERNÝ K, PEŠKOVÁ V 2013 Hymenoscyphus pseudoalbidus V. Queloz, C. R. Grünig, R. Berndt, T. Kowalski, T. N. Sieber et O. Holdenrieder (anamorfa Chalara fraxinea T. Kowalski): nekróza jasanů. Lesnická práce 92 (Attachment): I-IV http://www.silvarium.cz/images/letaky-los/2013/2013_nekroza_ jasanu.pdf

6. PEŠKOVÁ V, TUMA M. 2010 Ověření vlivu mykorhizního preparátu na růst a vývoj smrkových sazenic na LS Jablunkov. Zprávy lesnického výzkumu 55: 211-220

7. GRYNDLER M, BALÁŽ M, HRŠELOVÁ H, JANSA J, VOSÁTKA M 2004 Mykorhizní symbióza. O soužití hub s kořeny rostlin. Academia, Praha, p 368

8. CASTELLANO MA, TRAPPE JM 1991 Pisolithus tinctorius fails to improve plantation performance of inoculated conifers in southwestern Oregon. New forests http://dx.doi.org/10.1007/BF00118862

9. LAZEREVIĆ J, KEČA N, MARTINOVIĆ A 2012 Mycorrhization of containerized Pinus nigra seedlings with Suillus granulatus under open field conditions. Forest Systems 21: 498-507 http://revistas.inia.es/index.php/fs/article/view/2895

10. MITCHELL R J, COX G S, DIXON R K, GARRETT H E, SANDER I E 1984 Inoculation of three Quercus species with Eleven Isolates of Ectomycorrhizal Fungi. II: foliar Nutrient Content and Isolate Effectiveness. Forest Sci 30: 563-572 http://www.ingentaconnect.com/content/saf/ fs/1984/00000030/00000003/art00004

11. LUNT P, HEDGER J N 2003 Effects of Organic Enrichment of Mine Spoil on Growth and Nutrient Uptake in Oak Seedlings Inoculated with Selected Ectomycorrhizal Fungi. Restor Ecol 11: 125130 http://dx.doi.org/10.1046/j.1526-100X.2003.09968.x

12. NÚNEEZ J A D, SERRANO J S, BARREAL J A R, GONZÁLEZ J A S DE O 2006 The influence of mycorrhization with Tuber melanosporum in the afforestation of a Mediterranean site with Quercus ilex and Quercus faginea. Forest Ecol Manag 231: 226-233 http:// www.sciencedirect.com/science/article/pii/S0378112706003641
13. HERMANN S, OELMÜLLER R, BUSCOT F 2004 Manipulation of the onset of ectomycorrhiza formation by indole-3-acetic acid, activated charcoal or relative humidity in the association between oak microcuttings and Piloderma croceum: influence on plant development and photosynthesis. Journal Plant Physiol 161: 509-517 http://dx.doi.org/10.1078/0176-1617-01208

14. PRUETT G E, BRUHN J N, MIHAIL J D 2008 Colonization of Pedunculate oak by the Burgundy truffle fungus is greater with natural than with pelletized lime. Agroforest Syst 72: $41-50$ http:// link.springer.com/article/10.1007\%2Fs10457-007-9069-2

15. GARBAYE J, CHULIN J - L 1997 Growth stimulation of young oak plantations inoculated with the ectomycorrhizal fungus Paxilus involutus with special reference to summer drought. Forest Ecol Manag 98: 221-228 http://dx.doi.org/10.1016/S0378-1127(97)00105-9

16. TUČEKOVÁ A, LONGAUEROVÁ V, LEONTOVYČ R 2009 Poznatky z testovánia mykorhizovaného preparátu VAMBAC ${ }^{\circ}$ na smreku (Picea abies L.) v oblasti s dlhodobo zvýšeným stavom Armillaria sp. In: Česká lesnická společnost, o. s., Výzkumný ústav lesního hospodáŕství a myslivosti, v. v. i. Mykorhiza v lesích a možnosti její podpory. Česká lesnická společnost, Frýdek-Místek, p. 52-58

17. PEŠKOVÁ V, SOUKUP F 2006 Houby vázané na kořenové systémy: metodické př́stupy ke studiu. Review. Zprávy lesnického výzkuти 51: 279-286

18. KOCOUREK R 1991 Závislost odumírání smrku ztepilého (Picea abies (L.) Karst.) v imisních oblastech na ekologických charakteristikách ektomykorrhizních symbióz. Dissertation. Ústav krajinné ekologie, České Budějovice, p 137

19. PETERSON R L, MASSICOTTE H B, MELVILLE H $2004 \mathrm{My}$ corrhizas: anatomy and Cell Biology. NRC Research Press, Ottawa, p 173

20. CAISOVÁ V 1994 Hodnocení mykorhizace sazenic smrku pichlavého (Picea pungens) po aplikaci tekutého a suchého inokula lakovky (Laccaria proxima). Práce VÚLHM 79: 117/123.

21. VON BENNEWITZ F, HLUSEK J. 2006. Effect of the application of two biopreparations on the nutritional status, vegetative and generative behaviour of 'Jonagold' apple trees. In: Retamales J B (Ed) Proceedings of the Vth International Symposium on Mineral Nutrition of Fruit Plants. 5th International Symposium on Mineral Nutrition of Fruit Plants, Talca, Chile: p 129-135. http://dx.doi.org/10.17660/actahortic.2006.721.16

22. HOLUŠA J, PEŠKOVÁ V, VOSTRÁ M, PERNEKM 2009 Impact of mycorrhizal inoculation on spruce seedling: comparision of 5-year experiment in forests infested by honey fungus. Period Biol 111: 413-417 http://hrcak.srce.hr/file/73850

23. REPÁČ I, TUČEKOVÁ I, SARVAŠOVÁ I, VENCURIK I 2011 Survival and growth of outplanted seedlings of selected tree species on the High Tatra Mts. windthrow area after the first growing season. Journal of Forest Science 57: 349-358 http://www.agriculturejournals.cz/publicFiles/45145.pdf

24. GEBHARDT S, NEUBERT K, WÖLLECKE J, MÜNZENBERGER B, HÜTTL R F 2007 Ectomycorrhiza communities of red oak (Quercus rubra L.) of differentage in the Lusatian lignite mining district, East Germany. Mycorrhiza 17: 279-290 http://dx.doi.org/10.1007/s00572-006-0103-4

25. MEJSTŘíKV 1988 Mykorrhizní symbiózy. Academia, Praha, p 150.

26. REPÁČ I 2007 Ectomycorrhiza formation and growth of Picea ab$i e s$ seedlings inoculated with alginate-bead fungal inoculum in peat and bark compost substrates. Forestry 80: 517-530 http://dx.doi. org/10.1093/forestry/cpm036

27. SOUSA N R, FRANCO A R, RAMOS M A, OLIVEIRA R S CASTRO P. M. L 2011 Reforestation of burned stands: the effect of ectomycorrhizal fungi on Pinus pinaster establishment. Soil Biol Biochem 43: 2115-2120 http://www.sciencedirect.com/science/article/pii/S0038071711002422 
28. CASTELLANO M A 1996 Outplanting performance of mycorrhizal inoculated seedlings. In: Mukerji K G (Ed) Concepts in Mycorrhizal Research. Kluwer Academic Publishers, The Netherlands, p. 223-301 http://dx.doi.org/10.1007/978-94-017-1124-1_9
29. REPÁČ I 2007 Poznatky z aplikácie symbiotických húb při pestovaní semenáčikov borovice lesnej (Pinus sylvestris L.) In: Saniga M, Jaloviar P, Kucbel S (Eds) Obhospodarovanie lesa v meniacich sa podmienkach prostredia. Zborník povodných vedeckých prác. Technická univerzita, Zvolen, p. 163-170 